\title{
Deterrents to Participation in Sharing Economy Activities: Cross-Country Survey
}

\author{
Tatjana Tambovceva ${ }^{1}$, Jelena Titko ${ }^{2,}$, Anna Svirina ${ }^{3}$ and Maria Tereshina ${ }^{4}$ \\ ${ }^{1}$ Riga Technical University, Faculty of Engineering Economics and Management, Kalnciema 6, \\ LV1048 Riga, Latvia \\ 2 EKA University of Applied Sciences, Lomonosova 1/5, LV1019 Riga, Latvia \\ ${ }^{3}$ TISBI University of Management, 420012 Mushtari street, 13, Kazan, Russia \\ ${ }^{4}$ Kuban State University, Stavropolskaya ulitsa 149, 350040 Krasnodar, Russia
}

\begin{abstract}
Research background: Sharing economy is driven by a number of factors, such as intensified application of internet and smartphones, shift towards circular economy and sustainability, and globalization. An impact of globalization processes on consumer society is expressed not only in growth of international trade or development of transnational corporations, but also in change of cultural and communication patterns, specifically regarding change in attitudes towards ownership.

Purpose of the article: The goal of the research is to evaluate consumers' perception of a sharing economy. The current research continues the previous studies conducted by the authors but focuses on reasons for consumers' negative attitude towards sharing economy.

Methods: The study is conducted on the basis of survey results, which include 876 valid questionnaires. To understand the relationship between personal characteristics and lack of activity in sharing economy, the study implemented moderation statistical analysis. The choice of moderators was based on theoretical ground that estimates age, gender and education to influence person's choice on sharing economy; in this study those predictions are testing by means of moderation analysis.

Findings \& Value added: The authors tested the moderation effect of age, gender, and education on withdrawal from the sharing economy practices in relation to key sharing economy sectors (respondent was involved as service receiver/provider). Besides, the moderation effect of respondent's involvement into sharing economy as provider and receiver on withdrawal from the sharing economy practices in relation to key personal characteristics of the respondent was tested.
\end{abstract}

Keywords: sharing economy; sustainable development; globalization; survey

JEL Classification: D16; F60; $C 83$

\footnotetext{
* Corresponding author : jelena.titko@eka.edu.lv
} 


\section{Introduction}

Despite the extreme popularity of the sharing economy and the widespread use of this concept in public discourse, its generally accepted definition still does not exist (Botsman, 2013). Many researchers, for example, Guo et al. (2020), associate this situation with the "gap" between theory and rapidly developing sharing practices. First proposed by Weitzman (1984) as a model for reducing marginal costs in the wage system, the sharing economy has taken on a whole new multidimensional meaning with the development of the Internet and information and communication technologies (ICT). Currently, there are a number of definitions related to the sharing economy (digital economy, gig-economy, on-demand economy, collaborative economy, freelance economy, peer-to-peer economy, second hand economy etc.), the conceptualization of which, according to Dredge and Gyimóthy (2015) depends primarily on the subject research area. A number of authors believe that the sharing economy is based primarily on the technological innovations and new digital information (Pouri and Hilty, 2021), while others analyze the nature of the concept of the sharing economy based on the theory of transaction costs (Munger, 2019), property transfer (Jiang and Yin, 2019) or social value (Davlembayeva et al., 2020). Nevertheless, despite the diversity of approaches, most researchers agree that the main elements of the sharing economy model are sharing, increasing efficiency and saving resources. In a broad sense, the sharing economy includes various types of activities (exchange, lending, renting, donating) in three main areas: 1) service-product systems that provide access to products or services without the need to own underlying assets, 2) markets for the redistribution of tangible assets, and 3 ) "joint lifestyle", implying the exchange of intangible assets.

The concept of sharing economy is linked to the concept of circular economy - "both... focus on efficient and sustainable resource use by individuals, companies, and governments." (World Economic Forum, 2013) - and, obviously, it is related to sustainability through environmental-friendly/eco/green vision of development of society and business (Titko and Tambovceva, 2020; Areia etal., 2020).

In the ongoing debate over whether the sharing economy is a new ideology of sustainable consumption, or a business model based on benefits, it is of great importance to study the attitude of users towards it. The attitude of consumers towards the sharing economy is influenced by a complex of factors, many of which have been empirically identified by researchers. However, since both consumers and suppliers in that case are prosumers and have similar motives, some authors (Hawlitschek et al., 2016) conclude that the consumer perspective of motivation is dominant. In the literature about attitude towards sharing economy, positive factors are mainly associated with economic benefits, but others are also present, for example: hedonic motivation (Venkatesh et al., 2012), modern lifestyle, sense of belonging (Peterson et al, 2008), sustainability and environmental friendliness (Hamari et al., 2015), thriftiness (Lamberton and Rose, 2012), ubiquitous availability, etc. Although the influence of positive motives has been studied quite well (Chevalier and Mayzlin, 2006), it should be noted that there can be a significant gap between attitudes in general and direct involvement in sharing economy practices, since a positive attitude does not necessarily become an action. Negative factors are much less likely to become an object of research interest. Trust issues (Mayer and Davis, 1999; Tussyadiah, and Pesonen, 2016), privacy risks (Venkatesh and Bala, 2008), the pursuit of independence and prestige through property are among the main barriers that negatively affect the inclusion of users in sharing practices. (Botsman and Rogers, 2010), materialism as a consumer ideology, etc. It should be borne in mind that it is precisely negative factors in conditions of free diffusion of information that can play a decisive role in consumer decisions. This is due to the so-called negativity bias the effect, the essence of which is that the tendency of consumers to perceive negative information is much more than positive (Vaish et al., 2008). 
The authors' analysis of the literature shows that the structure of factors affecting consumer attitudes is quite dynamic, changes over time and significantly depends on age, cultural and gender context, which actualizes the problem of negative attitudes of various consumer groups towards the sharing economy.

\section{Methods}

This study continues the series of researches devoted to the investigation of attitude towards sharing economy, containing the pilot study (Tambovceva and Titko, 2020) with Latvian sample data and a cross-country research (the paper has been submitted to publishing in Sustainability journal).

The data has been collected through an online survey, using the questionnaire originally developed for survey of consumers in the United Kingdom and the United States (Veridu, 2016). The structure of the questionnaire is described in Table 1.

Table 1. The structure of the questionnaire

\begin{tabular}{|c|c|c|}
\hline Section A & Respondent profile & Details \\
\hline A1 & Age & Closed: 8 alternative responses \\
\hline A2 & Gender & Closed: 2 alternative responses \\
\hline A3 & Education level & Closed: 4 alternative responses \\
\hline A4 & $\begin{array}{l}\text { Self-perception as an eco-friendly } \\
\text { person }\end{array}$ & 5-point scale \\
\hline A5 & Household income per person & Closed: 6 alternative responses \\
\hline Section B & $\begin{array}{c}\begin{array}{c}\text { Experience in Sharing economy } \\
\text { services }\end{array} \\
\end{array}$ & Details \\
\hline B1 & $\begin{array}{c}\text { Experience as a Sharing Economy } \\
\text { services receiver }\end{array}$ & Multiple-choice: 9 alternatives \\
\hline B2 & $\begin{array}{l}\text { Experience as a Sharing Economy } \\
\text { services provider }\end{array}$ & Multiple-choice: 9 alternatives \\
\hline B3 & $\begin{array}{l}\text { Reasons for non-participation in } \\
\text { Sharing economy activities }\end{array}$ & Multiple-choice: 8 alternatives \\
\hline B4 & $\begin{array}{l}\text { Reasons for abandoning a Sharing } \\
\text { economy transaction }\end{array}$ & Multiple-choice: 6 alternatives \\
\hline Section $\mathrm{C}$ & Attitude to Sharing economy & Details \\
\hline $\mathrm{C} 1$ & $\begin{array}{c}\text { Self-perception in various Sharing } \\
\text { economy scenarios }\end{array}$ & C1.1-C1.8 statements \\
\hline $\mathrm{C} 2$ & $\begin{array}{l}\text { Perceived importance of Sharing } \\
\text { Economy services }\end{array}$ & C2.1-C2.9 statements \\
\hline $\mathrm{C} 3$ & Safety check & C3.1 - C3.6 statements \\
\hline
\end{tabular}

Source: Veridu (2016)

There were three different types of answers: 1) answering, using 5-point scale, such as "1 - not important; 5 - very important" for C2 question or "1 - extremely uncomfortable; 5 extremely comfortable" for $\mathrm{C} 1$ question; 2) answering by selecting one option from the proposed variants (B3, B4 questions); 3) answering by selecting several options from the proposed variants (B1, B2 questions).

In this particular study, the authors focused on reasons for non-participation in Sharing economy activities (B3 question) and reasons for abandoning a Sharing economy transaction (B4 question). 
In order to assess non-participation and abandoning of sharing economy, we have applied moderation and multilevel regression analysis to test the following hypothesis.

Hypothesis 1. Individual characteristics (age, gender, education, income, ecofriendliness, country of origin) are related to non-participation in the sharing economy activities.

Hypothesis 2. Individual characteristics (age, gender, education, income, ecofriendliness, country of origin) are related to abandoning of the sharing economy activities.

Hypothesis 3. Individual characteristics' (age, gender, education, income, ecofriendliness, country of origin) relation to non-participation in the sharing economy activities is moderated by the respondent's involvement in the sharing economy (receiver or provider).

Hypothesis 4. Individual characteristics' (age, gender, education, income, ecofriendliness, country of origin) relation to abandoning of the sharing economy activities is moderated by the respondent's involvement in the sharing economy (receiver or provider).

Moderation analysis was performed by means of SPSS Statistics 22.0 ; on the first stage a single independent variable regression analysis is performed which indicates whether the variable's influence is statistically significant; on the second stage the moderating variable is added, and it is considered the moderator if the first-stage independent variable's significance disappears.

Also, the multilevel automatic regression analysis was performed in a form of testing the individual characteristics significance nested by person's involvement in sharing economy as a provider of receiver.

Those two types of analysis were performed along with the graph analytics to test the above-mentioned hypothesis.

\section{Results}

At the first step of our analysis, we have defined non-participation in the sharing economy as a dependent variable, respondent's individual characteristics (age, gender, education, income, eco-friendliness, country of origin) as an independent variable, and involvement into sharing economy as a moderating variable. The results of the relevant regression analysis are in Table 2.

Table 2. Regression analysis results for non-participation in the sharing economy (moderatorinvolvement in the sharing economy practices)

\begin{tabular}{|l|c|c|c|c|c|}
\hline \multirow{2}{*}{$\begin{array}{l}\text { Independent } \\
\text { variable }\end{array}$} & \multicolumn{2}{|c|}{ Single factor model } & \multicolumn{3}{|c|}{ Model with the moderating variable } \\
\cline { 2 - 6 } & $\mathbf{R}^{\mathbf{2}}$ & Significance & $\mathbf{R}^{\mathbf{2}}$ & $\begin{array}{c}\text { Factor } \\
\text { significance }\end{array}$ & $\begin{array}{c}\text { Moderator } \\
\text { significance }\end{array}$ \\
\hline Age & 0.002 & 0.242 & 0.27 & 0.214 & 0.000 \\
\hline Gender & 0.000 & 0.907 & 0.26 & 0.984 & 0.000 \\
\hline Education & 0.000 & 0.665 & 0.26 & 0.579 & 0.000 \\
\hline $\begin{array}{l}\text { Eco- } \\
\text { friendliness }\end{array}$ & 0.002 & 0.220 & 0.27 & 0.300 & 0.000 \\
\hline Income & 0.002 & 0.219 & 0.27 & 0.227 & 0.000 \\
\hline
\end{tabular}

Source: own findings

The results clearly indicate there is no statistically significant relationship between individual characteristics of the person and his non-participation in the sharing economy practices. Also, the key motivation to participate in the sharing economy as a receiver is not a moderator for individual characteristics. Thus, both hypotheses 1 and 3 are not supported. At the same time, the reasoning behind involvement of an individual in the sharing economy practices is significantly related to the decision to not participate in sharing economy. Close, but even worse in terms of statistical significance, results were achieved when we have 
assessed person's involvement as a provider in the sharing economy practices (average $\mathrm{R}^{2}$ was 0.19 instead of 0.27 for receiver).

The same type of analysis was carried out for the abandoning of sharing economy practices, and the results can be seen in Table 3.

Table 2. Regression analysis results for abandoning sharing economy practices (moderatorinvolvement in the sharing economy practices)

\begin{tabular}{|l|c|c|c|c|c|}
\hline \multirow{2}{*}{$\begin{array}{l}\text { Independent } \\
\text { variable }\end{array}$} & \multicolumn{2}{|c|}{ Single factor model } & \multicolumn{3}{c|}{ Model with the moderating variable } \\
\cline { 2 - 6 } & $\mathbf{R}^{\mathbf{2}}$ & Significance & $\mathbf{R}^{\mathbf{2}}$ & $\begin{array}{c}\text { Factor } \\
\text { significance }\end{array}$ & $\begin{array}{c}\text { Moderator } \\
\text { significance }\end{array}$ \\
\hline Age & 0.000 & 0.856 & 0.005 & 0.761 & 0.218 \\
\hline Gender & 0.000 & 0.596 & 0.007 & 0.418 & 0.032 \\
\hline Education & 0.000 & 0.563 & 0.006 & 0.618 & 0.021 \\
\hline $\begin{array}{l}\text { Eco- } \\
\text { rriendliness }\end{array}$ & 0.003 & 0.128 & 0.009 & 0.092 & 0.015 \\
\hline Income & 0.000 & 0.624 & 0.007 & 0.620 & 0.019 \\
\hline
\end{tabular}

Source: own findings

As it can be seen for the Table 3, both hypotheses 2 and 4 are not supported. The quality of the model for abandoning sharing economy practices is even worse then for nonparticipation. At the same time, the quality of the model was better for sharing economy services providers, not receivers (as in case of non-participation). Thus one can come to a conclusion, that providers are more likely to abandon sharing economy practices then to refuse to participate - yet, this is to be tested within the separate research stream.

Due to the fact that the set of hypotheses was not supported, the authors implemented graphic analysis to reveal the most vague reasons for abandoning or being satisfied with sharing economy practices (see Fig. 1).

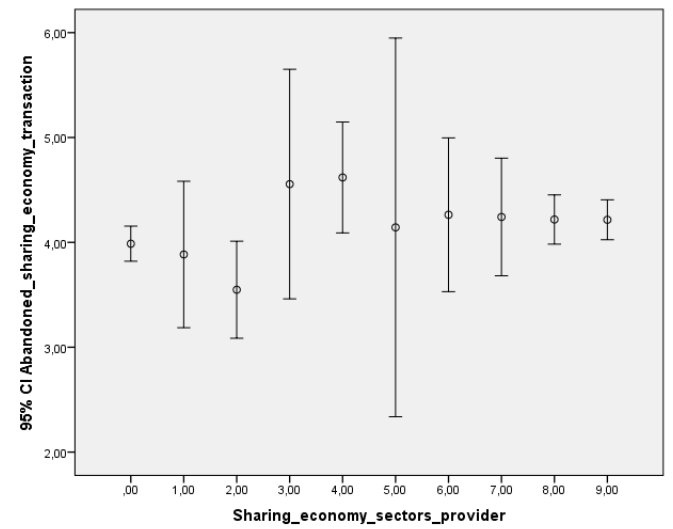

Figure 1. Graphic analysis of abandoning sharing economy practices

Source: own findings

As it can be seen from the Figure, the most difference for sharing economy services providers occur for those who were involved in crowdfunding and co-working spaces. Those people are more polarized on their reasoning behind abandoning their involvement in the sharing economy. Interest in crowdfunding is also the most turbulent factor for nonparticipation in the sharing economy (see Figure 2). 


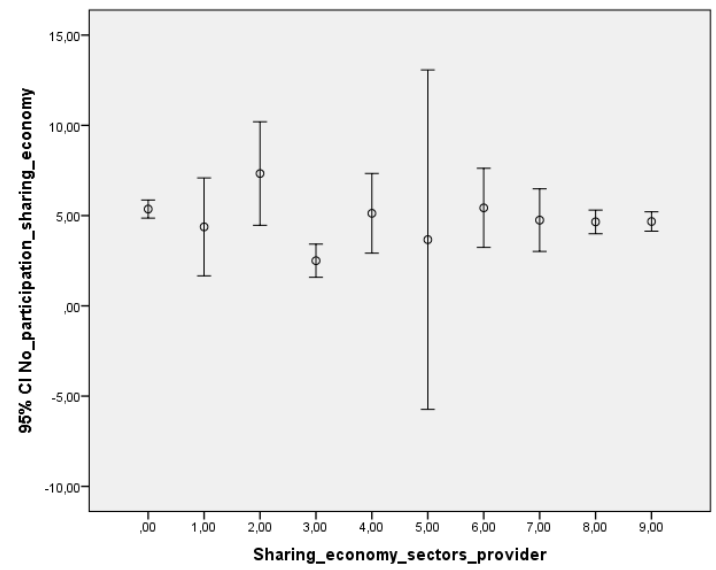

Figure 2. Graphic analysis of non-participation in the sharing economy.

Source: own findings

To finalize the research, we implemented multilevel regression analysis for both abandoning and non-participation in the sharing economy practices, which revealed that if nested by involvement in sharing economy, the key predictors for personal abandoning of sharing economy practices are a combination of gender, education and income; gender, education and eco-friendliness; age, education and income; age, education and ecofriendliness; for both receiver and provider. A combination of gender and education; country, age and education; age, education and income; age, education and eco-friendliness become good predictors for non-participation in sharing economy. Hence, it seems that involvement in sharing economy is a result of a set of personal characteristics, nested by personal sharing experience, rather than some general intend of an individual.

\section{Conclusions and Discussions}

The analysis presented above indicates that our findings a somewhat different from what one can find in the existing literature. First, we have not confirmed, that modern lifestyle, sense of belonging (Peterson et al, 2008), or sustainability and environmental friendliness (Hamari et al., 2015) are related to personal abandoning of sharing economy practices. On the opposite, our research indicates the issue is quite complex and requires studying multiple personal characteristics. At the same time, we have found no support for the idea that people avoid sharing economy practices due to privacy risks (Venkatesh and Bala, 2008), or the pursuit of independence and prestige through property. Though we did not have institutional issues in our questionnaire, a combination of country and income can give an idea of institutional development - and we have proven this combination to be statistically insignificant to influence personal abandoning or non-participation in the sharing economy practices. On the opposite, we have seen that a combination of age, gender and education becomes a better predictor for personal involvement - and none of these factors are relevant to institutional environment but indicate individual preferences.

\section{References}

1. Areia,A., Esteves,F., Santos,J. \& Anunciação,P. (2020).The DPOBE Model for Organizational Sustainability: An Exploratory Study about its Structure, Pillars and 
Components among a Group of Master Degree Students. Economics and Culture,17(1) 38-52.

2. Botsman, R. (2013, November 21). The Sharing Economy Lacks A Shared Definition. Fast Company. https://www.fastcompany.com/3022028/the-sharing-economy-lacks-ashared-definition

3. Botsman, R., \& Rogers R. (2010). What's Mine Is Yours: The Rise of Collaborative Consumption. New York: Harper Collins Publishers.

4. Chevalier, J. A., \& Mayzlin, D. (2006). The effect of word of mouth on sales: Online book reviews. Journal of Marketing Research, 43(3), 345-354.

5. Davlembayeva, D., Papagiannidis, S., \& Alamanos, E. (2020) Sharing economy: Studying the social and psychological factors and the outcomes of social exchange. Technological Forecasting and Social Change, 158, 120143.

6. Dredge, D., \& Gyimóthy, S. (2015). The Collaborative Economy and Tourism: Critical Perspectives, Questionable Claims and Silenced Voices. Tourism Recreation Researches, 40(3), 286-302

7. Guo, Y., Chen, J., Zhou, Y., \& Geng, J. (2020). Sharing Economy Platforms' Pricing Strategies and Decision Preferences: The Example of DiDi. Open Journal of Business and Management, 8, 1641-1656.

8. Hamari, J., Sjöklint, M., \& Ukkonen, A. (2015). The sharing economy: Why people participate in collaborative consumption. Journal of the Association for Information Science and Technology, 67(9), 2047-2059.

9. Hawlitschek, F., Teubner, T., \& Gimpel, H. (2016). Understanding the Sharing Economy--Drivers and Impediments for Participation in Peer-to-Peer Rental. In System Sciences (HICSS), 2016 49th Hawaii International Conference on (pp. 4782-4791). IEEE.

10. Jiang, H. Y., \& Yin, Q. F. (2019). Research on Equilibrium Model of Shared Consumer Market. Finance and Trade Research, 2, 27-37.

11. Lamberton, C. P., \& Rose, R. L. (2012). When is ours better than mine? A framework for understanding and altering participation in commercial sharing systems. Journal of Marketing, 76(4), 109-125.

12. Pouri, M. J., \& Hilty, L. M. (2021. The digital sharing economy: A confluence of technical and social sharing. Environmental Innovation and Societal Transitions, 38, 127-139.

13. Mayer, R. C., \& Davis, J. H. (1999). The effect of the performance appraisal system on trust for management: A field quasiexperiment. Journal of Applied Psychology, 84(1), 123-136.

14. Munger, M. C. (2018). Tommorow 3.0 : Transaction costs and the Sharing Economy. Cambridge University Press.

15. Peterson, N. A., Speer, P. W., \& McMillan, D. W. (2008). Validation of a brief sense of community scale: Confirmation of the principal theory of sense of community. Journal of Community Psychology, 36(1), 61-73.

16. Tambovceva, T., Titko, J. (2020). Consumer perception of sharing economy: pilot survey in Latvia. International Journal of Economic Policy in Emerging Economies (IJEPEE), 13(1), 72-84. http://www.inderscience.com/storage/f912671011124538.pdf

17. Tussyadiah, IP., \& Pesonen, J. (2016). Impacts of peer-to-peer accommodation use on travel patterns. Journal of Travel Research 55(8), 1022-1040. 
18. Vaish, A., Grossmann, T., \& Woodward, A. (2008). Not all emotions are created equal: The negativity bias in social-emotional development. Psychological Bulletin, 134(3), 383-403.

19. Venkatesh, V., \& Bala, H. (2008). Technology acceptance model and a research agenda on interventions. Decision Sciences, 39(2), 273-315.

20. Venkatesh, V., Thong, J., \& Xu, X. (2012). Consumer acceptance and use of information Technology: Extending the unified theory of acceptance and use of technology, MIS Quarterly, 36(1), 157-178.

21. Veridu (2016, July 7). What consumers really think of the Sharing Economy. https://medium.com/@VeriduHQ/what-consumers-really-think-of-the-sharingeconomy-89bdc5f9c55e

22. Weitzman, M. L. (1984). The Share Economy: Conquering Stagflation. Cambridge, MA: Harvard University Press.

23. World Economic Forum. (2013). Circular Economy Innovation \& New Business Models Dialogue. Young Global Leaders Sharing Economy Dialogue Position Paper. http://www3.weforum.org/docs/WEF_YGL_CircularEconomyInnovation_PositionPap er_2013.pdf 